\title{
Storage of soybean seeds: Packaging and modified atmosphere technology
}

\author{
André F. Capilheira ${ }^{1}$, Jerffeson A. Cavalcante ${ }^{1}$, Gizele I. Gadotti ${ }^{1}$, Bruna R. Bezerra ${ }^{1}$, \\ Nander F. Hornke ${ }^{1}$ \& Francisco A. Villela ${ }^{1}$ \\ ${ }^{1}$ Universidade Federal de Pelotas/Faculdade de Agronomia Eliseu Maciel/Programa de Pós Graduação em Ciência e Tecnologia de Semente. Capão \\ do Leão, RS, Brasil. E-mail: capilheira@hotmail.com - ORCID: 0000-0002-1680-1860; jerffeson_agronomo@hotmail.com (Corresponding author) \\ - ORCID: 0000-0001-7451-4475; gizele.gadotti@ufpel.edu.br - ORCID: 0000-0001-9545-6577; nanderhornke@gmail.com - ORCID: 0000-0002-6585- \\ 0060; brunarosa-@hotmail.com - ORCID: 0000-0003-3010-9659; francisco.villela@ufpel.edu.br - ORCID: 0000-0003-2174-735X
}

\begin{abstract}
The characteristics of materials used in packages for seed storage may have a negative influence in the deterioration process, causing future problems during the period of storage and in emergence in the field. In this study, the objective was to evaluate the physiological quality of soybean seeds, stored in different packages with and without the addition of $\mathrm{CO}_{2}$ (modified atmosphere), for different periods of storage and in uncontrolled environmental conditions. In order to carry out the experiment, a completely randomized design was used in a split-plot scheme, with three types of packages (permeable, hermetic package inside the permeable package and hermetic package inside the permeable package with $\mathrm{CO}_{2}$ injection) in the main plot and six storage periods (zero, 45, 90, 135, 180 and 225 days) in the subplot, with four repetitions, totaling 72 experimental units. In hermetic packages multi-layer paper was used with or without $\mathrm{CO}_{2}$ injection, stored them for 225 days and performed an assessment at regular intervals of 45 days. At each period, the seeds were submitted to tests for moisture content, germination, seedling emergence, accelerated aging and electrical conductivity. The hermetic package, with and without $\mathrm{CO}_{2}$ injection, decreases the speed of deterioration of soybean seeds. The hermetic package allows a higher physiological quality of soybeans compared to the permeable package, with a storage period of up to 180 days under uncontrolled environmental conditions. The addition of $\mathrm{CO}_{2}$ inside the hermetic packages favors the maintenance of the physiological quality of soybean seeds in storage.
\end{abstract}

Key words: Glycine max L., storage, physiological quality

\section{Armazenamento de sementes de soja: Tecnologia de embalagem e atmosfera modificada}

RESUMO: As características dos materiais utilizados nas embalagens para armazenamento de sementes podem influenciar negativamente no processo de deterioração, acarretando problemas futuros no período de armazenamento e na emergência em campo. Desta forma, objetivou-se avaliar a qualidade fisiológica de sementes de soja, armazenadas em diferentes embalagens com ou sem adição de $\mathrm{CO}_{2}$ (atmosfera modificada) em diferentes períodos e condições ambientais não controladas. Para a realização do experimento foi utilizado um lote de sementes de soja da cultivar SYN 1059 RR. Utilizou-se um delineamento inteiramente casualizado em esquema de parcelas subdivididas, com três tipos de embalagens (embalagem permeável, embalagem hermética dentro da embalagem permeável e embalagem hermética dentro da embalagem permeável com injeção de $\mathrm{CO}_{2}$ ) na parcela principal e seis períodos de armazenamento (zero, 45, 90, 135, 180 e 225 dias) na subparcela, com quatro repetições para cada tratamento, totalizando 72 unidades experimentais. Foram utilizadas embalagens de papel multifoliado, hermética e hermética com injeção de $\mathrm{CO}_{2}$, armazenadas por 225 dias e avaliação em intervalos regulares de 45 dias. A cada período, as sementes foram submetidas aos testes de grau de umidade, germinação, emergência de plântulas, envelhecimento acelerado e condutividade elétrica. A embalagem hermética, com e sem injeção de $\mathrm{CO}_{2}$, diminui a velocidade da deterioração das sementes de soja. A embalagem hermética permite uma maior qualidade fisiológica das sementes de soja comparativamente à embalagem permeável, no período de armazenamento de até 180 dias sob condições ambientais não controladas. A adição de $\mathrm{CO}_{2}$ no interior de embalagens herméticas favorece a manutenção da qualidade fisiológica de sementes de soja no armazenamento.

Palavras-chave: Glycine max L., longevidade, qualidade fisiológica 


\section{INTRODUCTION}

In order to guarantee the quality of the seeds after harvesting and processing, seed producers have adopted several storage techniques, since qualitative losses occur during this stage due to the deterioration process, which is stimulated by respiratory metabolic activity.

These seeds, because they are hygroscopic, vary with the fluctuations in the relative humidity of the air and temperature of the environment, thereby experiencing a varying degree of humidity during the period of storage (Silva et al., 2010). These variations are detrimental to the maintenance of physiological quality, increasing deterioration and culminating in lipid peroxidation, disruption of cell membranes and disintegration of the cell nucleus (Demidchik, 2015).

In order to minimize losses during storage, seed producers have adopted several technological alternatives for the maintenance of seed quality, including the use of impermeable packages, which tend to reduce environmental variations in seed metabolism (Oliveira et al., 2009; Silva et al., 2010; Donadon et al., 2015).

Another alternative is the use of carbon dioxide inside the packages since the reduction of the oxygen concentration and the increase of $\mathrm{CO}_{2}$ greatly reduce the metabolic rate of the seeds, making this a viable alternative for the conservation of the quality of soybean seeds (Aguiar et al., 2012).

The aim of this study was to evaluate the physiological quality of soybeans stored in different packages, with or without the addition of $\mathrm{CO}_{2}$ (modified atmosphere), for different time periods, under uncontrolled environmental conditions (conventional warehouse).

\section{Material ANd Methods}

The study was conducted at the Sementes Costa Beber, located in the city of Condor in the state of Rio Grande do Sul, Brazil, with geographic coordinates of $28^{\circ} 7^{\prime} 58.66^{\prime \prime} \mathrm{S}$ and $53^{\circ} 31^{\prime} 33.08^{\prime \prime} \mathrm{W}$ and altitude of $529 \mathrm{~m}$. The evaluation of the physiological quality of the seeds was carried out at the Didactic Laboratory of Seed Analysis of the Escola de Agronomia Eliseu Maciel of the Universidade Federal de Pelotas, Capão do Leão, RS, Brazil.

One lot of soybean seeds of cultivar SYN 1059 RR, harvested in 2014/2015, produced under normal climate conditions, and with temperature and relative humidity of $23{ }^{\circ} \mathrm{C}$ and $64 \%$, respectively (INMET, 2016), were used. The harvest was carried out in March 2015 at an average temperature of $21{ }^{\circ} \mathrm{C}$ and relative humidity of about $65 \%$.

Soybean seeds at the time of harvest had an average moisture content of $13 \%$. After the harvest, according to the strategy used by the industry, the seeds were pre-cleaned and stored until the month of June, after which they were submitted to conditioning operations.

After processing, the seeds were stored in three types of packages: first, permeable multi-layer paper; second, tight polyethylene (of $0.156 \mathrm{~mm}$ thickness) inside the multi-layer paper packaging; third, tight inside the multifoil paper packaging with the atmosphere modified by the injection of
$\mathrm{CO}_{2}$. Containers with a capacity of $30 \mathrm{~kg}$ were filled with $20 \mathrm{~kg}$ of seeds, which were then packed on wooden pallets.

A completely randomized design was used in a split-plot scheme, with three types of packages (permeable, hermetic package inside the permeable package and hermetic package inside the permeable package with $\mathrm{CO}_{2}$ injection) in the main plot and six storage periods $(0,45,90,135,180$ and 225 days) in the subplot, with four repetitions for each treatment, totaling 72 experimental units.

In the hermetic package with an atmosphere modified by the injection of $\mathrm{CO}_{2}$, the gas injection was carried out by means of a plastic hose inserted into the package in order to gradually expel the intergranular air. The package was designed to contain a valve for such a procedure.

During the storage period, the values of storage temperature and relative air humidity of the storage site (Figure 1) and inside the packages were quantified daily by means of sensors. In order to monitor the oxygen concentration during the test, the seeds were conditioned in 10 hermetic packages and individually evaluated during the periods of $10,17,24,51,100,135,180$ and 225 days of storage with the aid of an oxygen meter.

At each storage period, a seed sample was collected with the help of a simple sampler, packed in a paper bag, and then kept in a Styrofoam box. Subsequently, the sampled seeds were submitted to the following quality tests:

Water content: The greenhouse method was used with forced air circulation, at $105 \pm 3{ }^{\circ} \mathrm{C}$, for $24 \mathrm{~h}$, to obtain the results according to the Rules for Seed Analysis - RAS (Brazil, 2009). The results were expressed as a percentage.

Germination test: four repetitions of 50 seeds, distributed on rolls of moist germitest paper, had been previously moistened with distilled water in a ratio 2.5 times the weight of the dry paper. Rolls were prepared and packed in a germinator at $25^{\circ} \mathrm{C}$. The counts were performed five and eight days after sowing according to the RAS (Brazil, 2009).

Seedling emergence: four repetitions of 50 seeds were planted in beds, and the final count of the total number of seedlings emerged were counted at 14 days after sowing. The seedlings were considered as emerged whose cotyledons were entirely above the surface of the soil, with the leaves and with the margins no longer touching.

Accelerated aging: this was conducted following the methodology described by Marcos Filho (2015), using four repetitions distributed in a single layer of seeds on aluminum screens suspended inside gerbox-type plastic boxes functioning

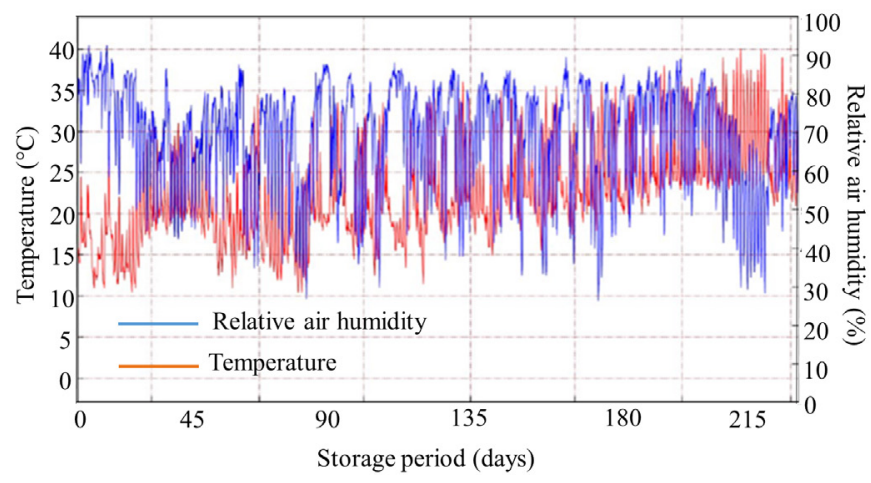

Figure 1. Relative air humidity and storage temperature (conventional storage), during storage period 
as individual compartments (minicams), with addition of 40 $\mathrm{mL}$ of water, and gerboxes were kept in an incubator (type BOD) at $42{ }^{\circ} \mathrm{C}$ for $48 \mathrm{~h}$. After this period, the same germination test procedure was followed, with evaluation at five days after sowing.

Electrical conductivity: four repetitions of 50 seeds were weighed on a $0.001 \mathrm{~g}$ precision scale and placed in plastic cups (200 mL capacity) containing $75 \mathrm{~mL}$ deionized water for $24 \mathrm{~h}$ at $25^{\circ} \mathrm{C}$, with a reading performed on a DM-32 benchtop conductivity meter (Vieira \& Krzyzanowski, 1999). The results were expressed as $\mu \mathrm{S} \mathrm{cm}^{-1} \mathrm{~g}^{-1}$.

The data were submitted to analysis of variance and, when significant, the packing types were compared by the Tukey test at $\mathrm{p} \leq 0.05$ and the storage periods submitted to polynomial regressions. The data were analyzed using the statistical program R.

\section{Results AND Discussion}

The concentration of oxygen present inside the hermetic packages, with and without $\mathrm{CO}_{2}$ injection, was constant up to 24 days of storage. Subsequent to this period, a reduction of the oxygen concentration was observed until the final storage period, with reduction of 7.5 and 5.0 percentage points between 24 and 225 days of storage, for packaging conditions with and without $\mathrm{CO}_{2}$ injection, respectively (Figure 2).

The final oxygen concentration inside the sealed containers, for the final storage period (225 days), was 10.7 and $12.6 \%$, respectively, for the packages with and without $\mathrm{CO}_{2}$ injection (Figure 2). These values were higher than the minimum oxygen concentration that can impose a limitation to respiration, which is $5 \%$, requiring the seeds to overcome this limitation to continue the metabolization of pyruvate by performing one or more forms of fermentation (Taiz et al., 2017).

Mussi (2005), when assessing the effect of $\mathrm{CO}_{2}$ on sunflower seeds, found that carbon dioxide caused a drastic reduction in the respiration rate of the seeds. This same author also observed that the $\mathrm{O}_{2}$ concentration is one of the main agents of the acceleration of the respiration of the seeds, next to water; the higher the concentration of carbon dioxide present inside the package, the better the maintenance of the germination of the

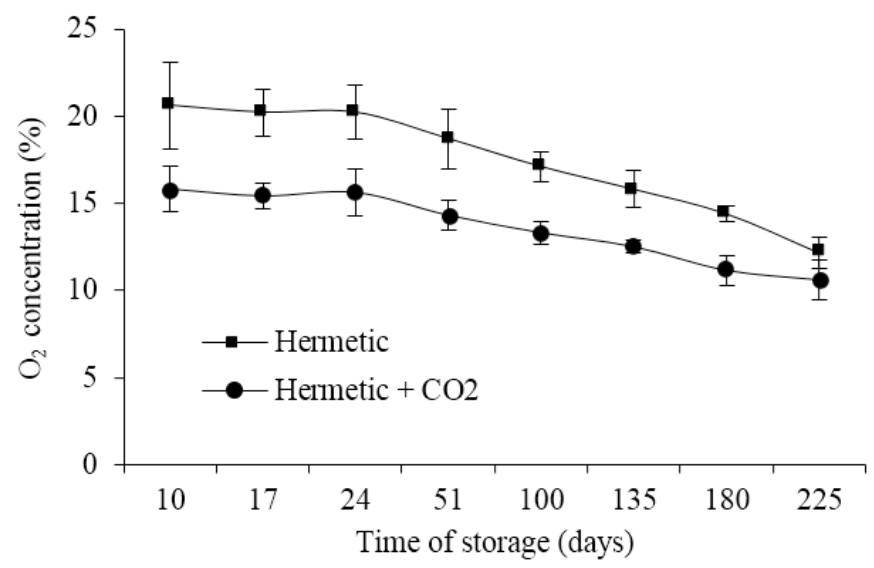

Figure 2. Oxygen concentration inside hermetic packaging during the storage of soybean seeds, with and without $\mathrm{CO}_{2}$ injection seeds, since metabolism during storage is reduced due to the decrease in oxygen concentration, thereby maintaining seed viability for a longer period of time.

Regarding the relative humidity of the air inside the multilayer package, peaks of humidity with a maximum of $79 \%$ and a minimum of $62 \%$ were observed, and the average humidity during the storage period was $73 \%$ (Figure $3 \mathrm{~A}$ ). As for the hermetic package, little moisture variation was observed during storage, with humidity during this period approximately $75 \%$ (Figure 3B).

During storage under uncontrolled conditions, the seeds are exposed to temperature and relative humidity oscillations, to the attacks of pests and effects of storage fungi, which may contribute to the reduction of their quality (Ludwig et al., 2011). These external variations can also cause changes in the internal environment of the containers in which the seeds are stored, and in these cases, can also occur due to resistance to gas exchange attributed to the permeability of each package.

Concerning the moisture content inside the packages (Figures $3 \mathrm{~A}$ and B), results may be associated with the sealing of each material. According to Baudet \& Villela (2012), when stored in permeable containers, the seeds alter their water content according to variations of the relative humidity of the air because they are hygroscopic. In semipermeable packages there is some resistance to gas exchange but it is insufficient to completely prevent the passage of moisture, whereas in impermeable packages there is no influence of the humidity of the external air on the seeds.

Variations of moisture inside the containers during storage cause variations in the water content of the seeds during this period, since the seed has hygroscopic tissues. When water loss occurs, the cell membranes undergo a process of structural disorganization, with partial or total modifications of the lamellar configuration of the membranes, and this increased disorganization leads to a lower water content of the seeds (Corrêa \& Afonso Júnior, 1999).

Considering that cell membranes are composed of a double layer of phospholipids, and that the hydrophobic-hydrophilic orientation structure depends on the presence of water for maintenance, the removal of water normally changes the membrane from the crystalline-liquid state to the gel state (Silva \& Villela, 2011). In the same way, when the water content increases, and this process becomes frequent, the membranes begin to lose their capacity to restructure when hydrated, accelerating the deterioration process of the stored seeds.

The temperature inside the multi-layer packages throughout the duration of storage showed a variation of $15^{\circ} \mathrm{C}$ between the maximum and minimum temperatures, 27 and $12{ }^{\circ} \mathrm{C}$, respectively, with the overall average being $20^{\circ} \mathrm{C}$ (Figure 3C). On the other hand, for the hermetic packages, the temperature ranged from 14 to $30{ }^{\circ} \mathrm{C}$, presenting an average temperature value of $25^{\circ} \mathrm{C}$ (Figure 3D).

Higher temperatures observed inside the airtight containers are expected, since the seeds, when alive, generally undergo active respiratory metabolism; this process is a heat sink, and because they are impermeable, hermetic packages prevent exchange of the inner medium with the external medium, thereby raising the temperature inside the packages. According 
A.
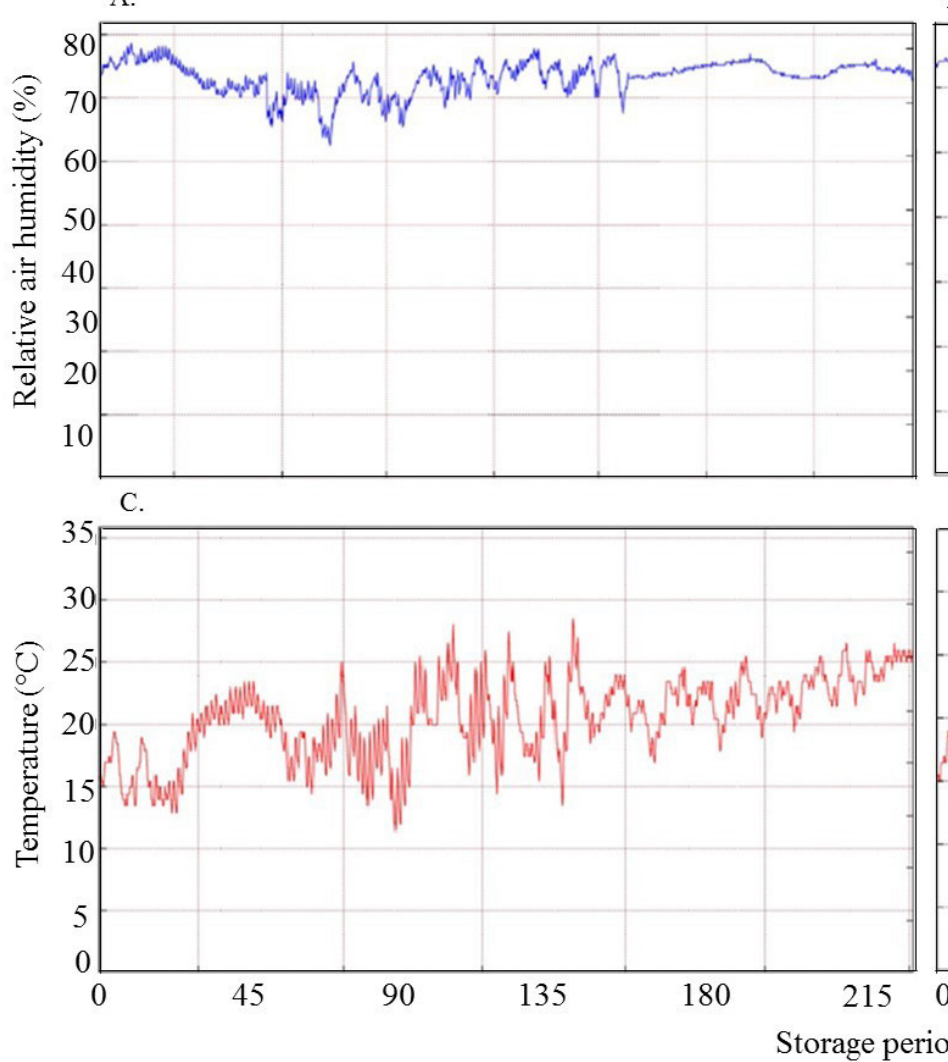

B.

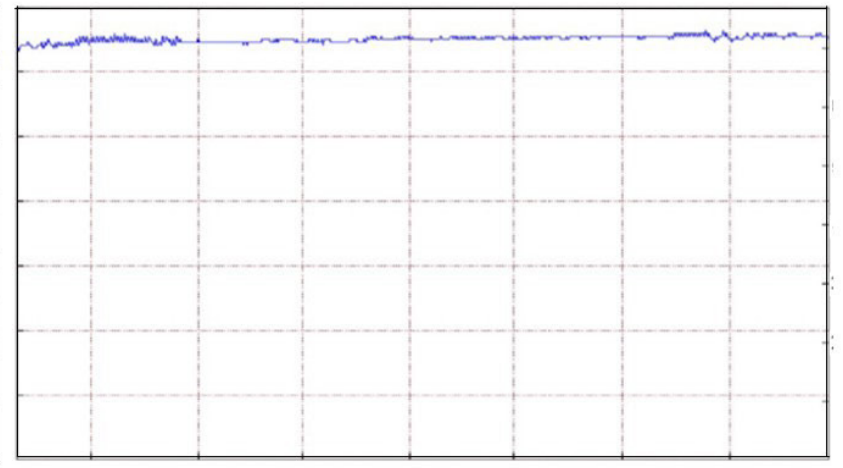

D.

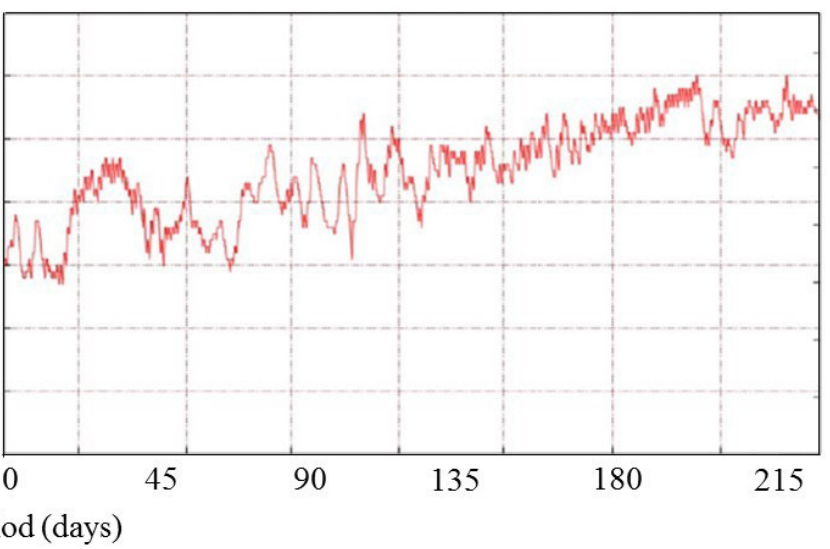

Figure 3. Variation of relative air humidity and temperature inside multi-layer paper containers (A and C) and hermetic (B and D) during the storage of soybean seeds in different types of packages with and without modified atmosphere

to Marini et al. (2012), temperatures above $25^{\circ} \mathrm{C}$ increases respiratory and enzymatic activities.

Stressful environmental conditions, such as high temperatures, lead to decreased G6PDH activity and decreased NADPH production, culminating in a decline in the activities of some NADPH-dependent antioxidant enzymes, which results in severe damage to the cell membrane structure, affecting seed quality (Kocsy et al., 2001; Kevers et al., 2004; Lin et al., 2004, 2005).

In relation to the moisture content of the seeds (Table 1), it was verified that the seeds stored in multi-layer paper packages presented, after 45 days of storage, water contents higher than the seeds stored in hermetic packages with and without injection of $\mathrm{CO}_{2}$. This fact stems from the impermeability of hermetic packages, which have as one of their main advantages the avoidance of the exchange of moisture of the seeds with the environment (Baudet \& Villela, 2012).

For the longest storage period (225 days), the soybean seeds packed in the multi-layer paper packaging had a water content of $12.8 \%$ (Table 1 ). This change in the water content of the seeds, which occurred during variations in the environmental conditions, are the result of hygroscopic equilibrium, one of the main causes of the acceleration of the process of seed deterioration.

When the germination of the seeds was evaluated (Table 1), a statistical difference was observed between the packing types only at 180 days of storage, in which the seeds stored in multilayer paper packages presented lower germination percentage than those stored in hermetic packages with and without $\mathrm{CO}_{2}$ additions, with the latter not differing from each other.
Table 1. Water content (WC), germination, electrical conductivity (EC), accelerated aging (AA) and emergence (E) of soybean seeds stored in different periods and packages

\begin{tabular}{|c|c|c|c|c|c|c|}
\hline \multirow{2}{*}{$\begin{array}{l}\text { Periods } \\
\text { (days) }\end{array}$} & \multirow{2}{*}{ Packages } & WC & Germination & Emergence & AA & \multirow{2}{*}{$\begin{array}{c}E C \\
\left(\mu S \mathrm{~cm}^{-1} \mathrm{~g}^{-1}\right)\end{array}$} \\
\hline & & \multicolumn{4}{|c|}{$(\%)$} & \\
\hline \multirow{3}{*}{0} & Paper & $11.8 \mathrm{a}$ & $96 \mathrm{a}$ & $91 \mathrm{a}$ & $87 \mathrm{a}$ & $70.85 \mathrm{a}$ \\
\hline & Hermetic & $11.6 \mathrm{a}$ & $96 \mathrm{a}$ & $92 \mathrm{a}$ & $88 \mathrm{a}$ & $71.94 \mathrm{a}$ \\
\hline & Hermetic $+\mathrm{CO}_{2}$ & $12.0 \mathrm{a}$ & $95 \mathrm{a}$ & $91 \mathrm{a}$ & $85 \mathrm{a}$ & $73.38 \mathrm{a}$ \\
\hline \multirow{3}{*}{45} & Paper & $11.8 \mathrm{a}$ & $95 \mathrm{a}$ & $90 \mathrm{a}$ & $78 \mathrm{a}$ & $75.28 \mathrm{a}$ \\
\hline & Hermetic & $11.8 \mathrm{a}$ & $95 \mathrm{a}$ & $90 \mathrm{a}$ & $83 \mathrm{a}$ & $73.41 \mathrm{a}$ \\
\hline & Hermetic $+\mathrm{CO}_{2}$ & $11.4 \mathrm{a}$ & $93 \mathrm{a}$ & $89 a$ & $82 \mathrm{a}$ & $74.13 \mathrm{a}$ \\
\hline \multirow{3}{*}{90} & Paper & $12.0 \mathrm{a}$ & $96 \mathrm{a}$ & $89 a$ & $72 b$ & $81.10 \mathrm{a}$ \\
\hline & Hermetic & $11.2 b$ & $96 \mathrm{a}$ & $90 \mathrm{a}$ & $81 \mathrm{a}$ & $79.04 \mathrm{a}$ \\
\hline & Hermetic $+\mathrm{CO}_{2}$ & $11.2 \mathrm{~b}$ & $96 \mathrm{a}$ & $87 \mathrm{a}$ & $81 \mathrm{a}$ & $77.09 \mathrm{a}$ \\
\hline \multirow{3}{*}{135} & Paper & $12.8 \mathrm{a}$ & $92 \mathrm{a}$ & $87 \mathrm{a}$ & $66 \mathrm{~b}$ & $84.31 \mathrm{a}$ \\
\hline & Hermetic & $11.8 \mathrm{~b}$ & $92 \mathrm{a}$ & $88 \mathrm{a}$ & $72 \mathrm{a}$ & $81.07 \mathrm{a}$ \\
\hline & Hermetic $+\mathrm{CO}_{2}$ & $11.4 \mathrm{~b}$ & $92 \mathrm{a}$ & $85 \mathrm{a}$ & $74 \mathrm{a}$ & $82.45 \mathrm{a}$ \\
\hline \multirow{3}{*}{180} & Paper & $14.0 \mathrm{a}$ & $78 \mathrm{~b}$ & $71 \mathrm{~b}$ & $39 \mathrm{~b}$ & $102.65 \mathrm{a}$ \\
\hline & Hermetic & $11.2 \mathrm{~b}$ & $90 \mathrm{a}$ & $84 \mathrm{a}$ & $60 \mathrm{a}$ & 89.54 b \\
\hline & Hermetic $+\mathrm{CO}_{2}$ & $11.8 b$ & $92 \mathrm{a}$ & $83 a$ & $66 \mathrm{a}$ & $88.51 b$ \\
\hline \multirow{4}{*}{225} & Paper & $12.8 \mathrm{a}$ & $45 c$ & $38 \mathrm{c}$ & $19 \mathrm{C}$ & $170.78 \mathrm{a}$ \\
\hline & Hermetic & $11.8 \mathrm{~b}$ & $63 \mathrm{~b}$ & $50 \mathrm{~b}$ & $39 \mathrm{~b}$ & $122.74 \mathrm{~b}$ \\
\hline & Hermetic $+\mathrm{CO}_{2}$ & $11.6 \mathrm{~b}$ & $82 \mathrm{a}$ & $72 a$ & $47 \mathrm{a}$ & $128.39 \mathrm{~b}$ \\
\hline & CV (\%) & 4.76 & 3.58 & 3.96 & 5.74 & 9.45 \\
\hline
\end{tabular}

Means followed by the same letter, in the column, in each period, do not differ from each other, by the Tukey test at $\mathrm{p} \leq 0.05$

The seeds stored in the packages of multi-layer paper (Table 1) presented germination percentages at the end of the storage period lower than the minimum commercial standard established by Normative Instruction No. 45, of September 17, 2013 for this crop, which is $80 \%$ (Brazil, 2013). Seeds stored in sealed containers, with or without $\mathrm{CO}_{2}$ injection, maintained germination percentages equal to or greater than $90 \%$, which is suitable for commercialization. However, at 225 days of storage, only the seeds stored in sealed containers with and without the 
injection of $\mathrm{CO}_{2}$ presented germination percentages above the minimum required for commercialization.

Seeds stored in sealed containers with and without $\mathrm{CO}_{2}$ added had higher emergence percentages than those stored in multi-layer paper at 180 days of storage (Table 1). However, at 225 days, all the packages provided different conditions, with the seeds being conditioned under hermetic conditions with $\mathrm{CO}_{2}$ injection presenting greater levels of vigor than those stored in multi-layer and hermetically sealed packages without addition of $\mathrm{CO}_{2}$ (Table 1).

It was observed that at up to 135 days of storage, seed vigor was not affected regardless of the type of packaging used (Table 1). However, from 180 to 225 days of storage, the vigor of the seeds stored in multi-layer paper packages was lower than that of the seeds stored in the hermetic packages, either with or without $\mathrm{CO}_{2}$ addition, when accelerated aging was evaluated (Table 1).

Since multi-layer paper packages are classified as permeable (Baudet \& Villela, 2012) and the temperature and relative humidity of the air inside the package (Figure 3 ) and in the storage site (Figure 1) showed variations during storage, such conditions may have caused the degradation of the membranes, as shown in the electrical conductivity test results in Table 1, as well as promoted the deterioration process and consequently the loss of vigor, especially over periods from 180 to 225 days.

According to Costa et al. (2008), the interaction between the initial water content of the seeds and the imbibition temperature is a determining factor for the occurrence of permanent or transient changes in the structure of the cell membranes.

The variables germination, emergence, accelerated aging and electrical conductivity presented quadratic behaviors for all packages as a function of the storage period (Figure 4).

A
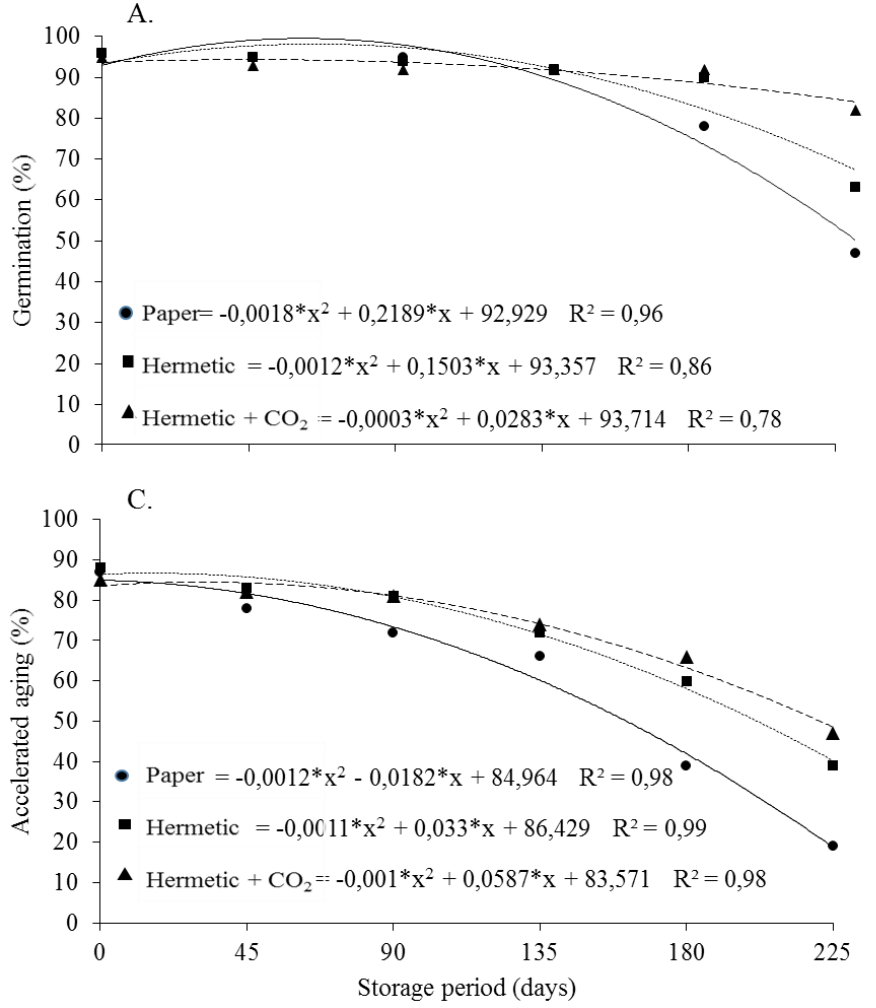

When the germination behavior of each type of packaging during storage was evaluated (Figure 4A), it was observed that the seeds stored in multi-layer paper packages showed maximum germination at 47 days of storage, with a maximum of $99.24 \%$. Subsequently, after this period, a reduction of 43 percentage points was observed until the last storage period.

However, seeds stored in sealed containers, without the addition of $\mathrm{CO}_{2}$, showed a maximum germination rate of $98.06 \%$ at 63 days of storage, with a reduction until the end of the period over which the seeds were stored, and finally presenting a germination rate below 70\% (Figure 4A). Seeds stored in hermetically sealed containers with $\mathrm{CO}_{2}$ addition provided the best storage conditions for the maintenance of germination, where at the end of the storage period the seeds had a minimum germination of $84.89 \%$ (Figure $4 \mathrm{~A}$ ).

Smaniotto et al. (2014) state that seeds tend to lose their potential to germinate during storage due to lipid peroxidation, variations in water content and seed temperature. However, even if viability loss occurs, considering that the validity of the germination test is 6 months (180 days) (Brazil, 2013), it was observed that the seeds stored in the hermetic packages, with and without the addition of $\mathrm{CO}_{2}$, maintained their viability above the minimum germination standard for up to 180 days, remaining suitable for commercialization.

The same tendency for an increase and a later decrease in the germination potential of the seeds during the periods of storage was verified in the results of the seedling emergency test, which verified a reduction in the emergence of seedlings at around 70 days of storage for all the packaging types; however, the seeds packed in the hermetically-sealed container with $\mathrm{CO}_{2}$ presented the highest percentage of emergence, with value higher than $70 \%$ (Figure $4 \mathrm{~B}$ ) at the end of storage.
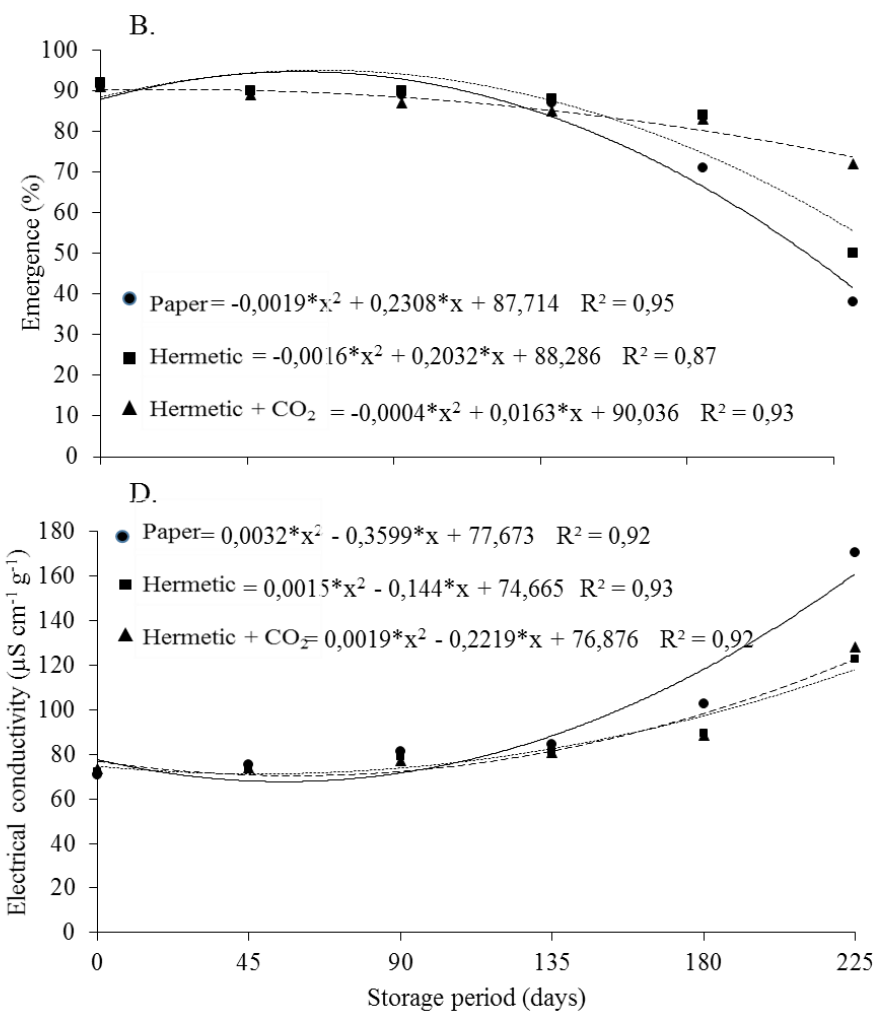

* - Significant at $\mathrm{p} \leq 0.05$ by F test

Figure 4. Germination (A), emergence (B), accelerated aging (C) and electrical conductivity (D) of soybean seeds stored as function of storage periods and packages 
Seed vigor can be related to resistance to the humidity variations that the hermetic material offers and to the modification of the atmosphere, since, according to Marcos Filho (2015), deterioration of the seeds is also associated with the characteristics of the packaging because there are materials that do not provide resistance to the gas exchange between the seeds and the atmosphere, as well as to the concentration of $\mathrm{O}_{2}$ inside the packages which interferes with metabolism.

The vigor of the stored seeds, evaluated by the accelerated aging test, regardless of the type of packaging used, was low when compared to the results obtained in the seedling emergence test, being less than $50 \%$ at the end of the storage period (Figure 4C). According to Rosseto et al. (2001), the accelerated aging test results can be affected by the water absorption difference of the seeds and also by initial contamination by microorganisms, thus interfering with the interpretation of the data.

The degradation of the cell membranes of the stored seeds began to intensify around the 45 days of storage, at which time the greatest humidity variations occurred within the paper packages; however, this behavior affected all types of packages. At the end of the storage period, the seeds packed in multi-layer packages presented the highest ion leaching throughout the storage, as observed in the electrical conductivity test (Figure 4D).

Seed vigor is directly related to the integrity of cell membranes. Thus, more deteriorated seeds present a slower rate of restoration of cell membrane integrity during the hydration process, releasing larger amounts of solutes to the external environment (Milošević et al., 2010) and resulting in the reserves that would be destined for the resumption of embryo growth to be interrupted during germination and emergence in the field.

It is worth noting that even the seeds kept in the hermetic package (without and with $\mathrm{CO}_{2}$ injection) suffered a reduction of vigor, with greater intensity after 90 days of storage. This occurrence may be because the soybean seeds had been packaged in the impermeable packaging with humidity above $11 \%$. These conditions of humidity, high relative to the standards of hermetic packaging, allow the development of storage fungi; in addition, the presence of foreign organisms, temperature, storage conditions and the oxygen concentration (Scariot et al., 2018) may favor the process of seed deterioration.

In addition to the results of this work, it was observed that one of the great challenges for seed companies has been the evaluation of the physiological potential of commercial lots and the effective conservation of seeds during storage (Nery et al., 2009), which has led them to seek technical improvements in their activities within the production process, such as the search for new packaging technologies and a controlled atmosphere within packages.

\section{Conclusions}

1. Hermetic packaging, without and with $\mathrm{CO}_{2}$ injection, delays the deterioration of soybean seeds during storage.

2. The hermetic package without and with $\mathrm{CO}_{2}$ injection allows higher physiological quality of the soybean seeds compared to the permeable packaging over a storage period up to 180 days in uncontrolled environmental conditions.
3. The addition of $\mathrm{CO}_{2}$ inside hermetic packages favors the maintenance of the physiological quality of soybean seeds in storage.

\section{Literature Cited}

Aguiar, R. W. de S.; Brito, D. R.; Ootani, M. A.; Fidelis, R. R.; Peluzio, J. N. Efeito do dióxido do carbono, temperatura e armazenamento sobre sementes de soja e micoflora associada. Revista Ciência Agronômica, v.43, p.554-560, 2012. https://doi.org/10.1590/ S1806-66902012000300019

Baudet, L.; Villela, F. A. Armazenamento de sementes. In: Peske, S. T.; Villela, F. A.; Meneghello, G. E. Sementes: Fundamentos científicos e tecnológicos. Pelotas: UFPEL, 2012. Cap.7, p.481-527.

Brasil. Ministério da Agricultura, Pecuária e Abastecimento. Regras para análise de sementes. Secretaria de Defesa Agropecuária. Brasília: MAPA/ACS, 2009. 399p.

Brasil. Ministério da Agricultura, Pecuária e Abastecimento. Instrução Normativa $n^{\circ}$ 45, de 17 de setembro de 2013. Brasília, MAPA. 2013. Padrões para a produção e a comercialização de sementes. p.6-27. Seção 1.

Corrêa, P. C.; Afonso Júnior, P. C. Uso do teste de condutividade elétrica na avaliação dos danos provocados por diferentes taxas de secagem em sementes de feijão. Revista Brasileira de Produtos Agroindustriais, v.1, p.21-26, 1999. https://doi.org/10.15871/15178595/rbpa.v1n1p21-26

Costa, C. J.; Villela, F. A.; Bertoncello, M. R.; Tillmann, M. A. A.; Menezes, N. L de. Pré-hidratação de sementes de ervilha e sua interferência na avaliação do potencial fisiológico. Revista Brasileira de Sementes, v.30, p.198-207, 2008. https://doi. org/10.1590/S0101-31222008000100025

Demidchik, V. Mechanisms of oxidative stress in plants: From classical chemistry to cell biology. Environmental and Experimental Botany, v.109, p.212-228, 2015. https://doi.org/10.1016/j. envexpbot.2014.06.021

Donadon, J. R.; Bessa, J. F. V.; Resende, O.; Castro, C. F. de S.; Alves, R. M. V.; Silveira, E. V. Armazenamento do crambe em diferentes embalagens e ambientes: Parte II - Qualidade química. Revista Brasileira de Engenharia Agrícola e Ambiental, v.19, p.231-237, 2015. https://doi.org/10.1590/1807-1929/agriambi.v19n3p231-237

INMET - Instituto Nacional de Meteorologia. Banco de dados meteorológicos para ensino e pesquisa. Brasília: Instituto Nacional de Meteorologia, 2016. Available on: <http://www. inmet.gov.br/portal/index.php?r=bdmep/bdmep $>$. Accessed on: Maio 2018.

Kevers, C.; Franck, T.; Strasser, R. J.; Dommes, J.; Gaspar, T. Hyperhydricity of micropropagated shoots: A typically stressinduced change of physiological state. Plant Cell, Tissue and Organ Culture, v.77, p.181-191, 2004. https://doi.org/10.1023/ B:TICU.0000016825.18930.e4

Kocsy, G.; Galiba, G.; Brunold, C. Role of glutathione in adaptation and signaling during chilling and cold acclimation in plants. Physiology Plant, v.113, p.158-164, 2001. https://doi.org/10.1034/ j.1399-3054.2001.1130202.x

Lin, S. Z.; Zhang, Z. Y.; Lin, Y. Z.; Zhang, Q.; Gou, H. The role of calcium and calmodulin in freezing-induced freezing resistance of Populus tomentosa cuttings. Journal of Plant Physiology and Molecular Biology, v.30, p.59-68, 2004. 
Lin, S. Z.; Zhang, Z. Y.; Liu, W. F.; Lin, Y. Z.; Zhang, Q.; Zhu, B. Q. Role of glucose-6-phosphate dehydrogenase in freezing-induced freezing resistence of Populus suaveolens. Journal of Plant Physiology and Molecular Biology, v.31, p.34-40, 2005.

Ludwig, M. P.; Lucca Filho, O. A.; Baudet, L.; Dutra, L. M. C.; Avelar, S. A. G.; Crizel, R.L. Qualidade de sementes de soja armazenadas após recobrimento com aminoácido, polímero, fungicida e inseticida. Revista Brasileira de Sementes, v.33, p.395-406, 2011. https://doi.org/10.1590/S0101-31222011000300002

Marcos Filho, J. Fisiologia de sementes de plantas cultivadas. 2.ed. Londrina: Abrates, 2015. 660p.

Marini, P.; Moraes, C. L.; Marini, N.; Moraes, D. M. de; Amarante, L do. Alterações fisiológicas e bioquímicas em sementes de arroz submetidas ao estresse térmico. Revista Ciência Agronômica, v.43, p.722-730, 2012. https://doi.org/10.1590/S1806-66902012000400014

Milošević, M.; Vujaković, M.; Karagić, Đ. Vigour tests as indicators of seed viability. Genetika, v.42, p.103-118, 2010. https://doi. org/10.2298/GENSR1001103M

Mussi, M. M. Germinação e vigor de sementes de girassol (Helianthus annuus L.) submetidas a diferentes concentrações de $\mathrm{CO}_{2}$, períodos de exposição e embalagens. Curitiba: UFPR, 2005. 66p. Dissertação Mestrado

Nery, M. C.; Carvalho, M. L. M. de; Guimarães, R. M. Testes de vigor para avaliação da qualidade de sementes de nabo forrageiro. Informativo Abrates, v.19, p.9-20, 2009.

Oliveira, M. T. de; Berbet, P. A.; Pereira, R. de C.; Vieira, H. D.; Thiébaut, J. T. L.; Carlesso, V. de O. Qualidade fisiológica e potencial de armazenamento de sementes de carambola. Revista Brasileira de Sementes, v.31, p.236-244, 2009. https://doi. org/10.1590/S0101-31222009000200028
Rosseto, C. A. V.; Bassin, C. A.; Carmo, M. G. F.; Nakagawa, J. Tratamento fungicida, incidência de fungos e momento de avaliação da germinação no teste de envelhecimento acelerado em sementes de amendoim. Revista Brasileira de Sementes, v.23, p.78-87, 2001. https://doi.org/10.17801/0101-3122/rbs. v23n $2 \mathrm{p} 78-87$

Scariot, M. A.; Radünza, L. L.; Dionelloa, R. G.; Toni, J. de R.; Mossi, A. J.; Reichert Júnior, F. W. Quality of wheat grains harvested with different moisture contents and stored in hermetic and conventional system. Journal of Stored Products Research, v.75, p.29-34, 2018. https://doi.org/10.1016/j.jspr.2017.11.005

Silva, F. S. da; Porto, A. G.; Pascuali, L. C.; Silva, F. T. C. da. Viabilidade do armazenamento de sementes em diferentes embalagens para pequenas propriedades rurais. Revista de Ciências Agroambientais, v.8, p.45-56, 2010.

Silva, K. da R. G. da; Villela, F. A. Pré-hidratação e avaliação do potencial fisiológico de sementes de soja. Revista Brasileira de Sementes, v.33, p.331-345, 2011. https://doi.org/10.1590/S010131222011000200016

Smaniotto, T. A. de S.; Resende, O.; Marçal, K. A. F.; Oliveira, D. E. C. de; Simon, G. Qualidade fisiológica das sementes de soja armazenadas em diferentes condições. Revista Brasileira de Engenharia Agrícola e Ambiental, v.18, p.446-453, 2014. https:// doi.org/10.1590/S1415-43662014000400013

Taiz, L.; Zeiger, E.; Moller, I. M.; Murphy, A. Fisiologia e desenvolvimento vegetal. 6.ed. Porto Alegre: Artmed, 2017. 888p.

Vieira, R. D.; Krzyzanowski, F. C. Teste de condutividade elétrica. In: Krzyzanowski, F. C.; Vieira, R. D.; França Neto, J. B. Vigor de sementes: Conceitos e testes. Londrina: Abrates, 1999. Cap.4, p.1-20. 